\title{
Biogas Production Using Water Hyacinth (Eicchornia crassipes) for Electricity Generation in Kenya
}

\author{
Paul Njogu $^{1 *}$, Robert Kinyua1, Purity Muthoni', Yusuyuki Nemoto \\ ${ }^{1}$ Institute of Energy and Environmental Technology, Jomo Kenyatta University of Agriculture and Technology, \\ Kenya \\ ${ }^{2}$ Division of Renewable Energy and Environment, Ashikaga Institute of Technology, Japan \\ Email: ${ }^{*}$ njogupaul@jkuat.ac.ke, ${ }^{*}$ njogupl@yahoo.com
}

Received 5 February 2015; accepted 15 May 2015; published 18 May 2015

Copyright (C) 2015 by authors and Scientific Research Publishing Inc.

This work is licensed under the Creative Commons Attribution International License (CC BY). http://creativecommons.org/licenses/by/4.0/

(c) (i) Open Access

\section{Abstract}

Water hyacinth, E. crassipes, an invasive water weed thrives in fresh water bodies causing serious environmental problems. In Kenya the weed has invaded Lake Victoria and poses great socioeconomic and environmental challenges. Currently the weed is harvested from the Lake and left in the open to rot and decay leading to loss of aesthetics, land and air pollution. There is therefore need for development of value addition and economic exploitation strategies. The aim of the study is to assess the potential for utilization of the weed as a renewable energy resource for biogas production. Samples were collected from Lake Victoria, pulped and blend with cow dung at a ratio of $3: 1$ as inoculum. The resultant mixture was mixed with water at a ratio of $1: 1$ and fed into a $6 \mathrm{~m}^{3}$ tubular digester. The digester was recharged with $20 \mathrm{~kg}$ after every three days. The temperature, pH variations, gas compositions, upgrading and gas yields were studied. The temperature ranged between $22.8^{\circ} \mathrm{C}-36.6^{\circ} \mathrm{C}$ and $\mathrm{pH} 7.4-8.5$. Biogas was found to contain $49 \%$ - $53 \%$ methane $\left(\mathrm{CH}_{4}\right)$, $30 \%-33 \%$ carbon dioxide $\left(\mathrm{CO}_{2}\right), 5 \%-6 \%$ nitrogen $\left(\mathrm{N}_{2}\right)$ and traces of hydrogen sulphide $\left(\mathrm{H}_{2} \mathrm{~S}\right)$. The biogas was upgraded using solid adsorbents and wet scrubbers increasing the methane content by up to $70 \%-76 \%$. The upgraded gas was used to power internal combustion engines coupled with an electricity generator and direct heat applications. The study concludes that $E$. crassipes is a potential feedstock for biogas production especially in areas where it is abundant.

\section{Keywords}

Renewable Energy, Biogas, Water Hyacinth, E. crassipes, Pollution

\footnotetext{
${ }^{*}$ Corresponding author.
}

How to cite this paper: Njogu, P., Kinyua, R., Muthoni, P. and Nemoto, Y. (2015) Biogas Production Using Water Hyacinth (Eicchornia crassipes) for Electricity Generation in Kenya. Energy and Power Engineering, 7, 209-216. 


\section{Introduction}

Biogas is a clean and environment friendly fuel produced through the anaerobic digestion of organic wastes such as: cow-dung, vegetable wastes, municipal solid waste and industrial wastewater [1] [2]. It is increasingly becoming important in domestic and industry as fuel due to its costs and cleanliness. The main component of the gas is methane, carbon dioxide, hydrogen, nitrogen and hydrogen sulphide [3]. Water hyacinth can be used as a potential feedstock for biogas production due to its abundance and high carbon-nitrogen ratio. This study aims at evaluating the potential of utilization of water hyacinth for biogas production.

\subsection{Water Hyacinth}

Water hyacinth, Eichhornia crassipes, is a floating plant, an invasive nuisance planta non grata in much of the world where it often jams rivers and lakes with tons of floating plant matter [4]. A healthy acre of water hyacinth can weigh up to 200 tons [4]. It grows in freshwater and has lavender flowers and round leathery leaves attached on spongy stalks. The plant has dark feathery roots.

E. crassipes form mats that clog waterways making fishing impossible and reduces water flow. Mats may double their size in as little as 6 - 18 days [5]. It degrades water quality by blocking the air-water interface and greatly reducing oxygen levels in the water, eliminating underwater animals such as fish and greatly reduces bio-diversity: mats eliminate native submersed plants by blocking sunlight, alter immersed plant communities by pushing them away and crushing them, and also alter animal communities by blocking access to the water and/or eliminating plants the animals depend on for shelter and nesting [7]. Millions of dollars a year used to be spent on water hyacinth control [8]-[10]. Several methods have been developed to help in its management: mechanical harvesters and chopping, biological controls (insects, fish) and use of water hyacinth registered aquatic herbicides [10].

\subsection{Anaerobic Digestion Process}

Biogas is produced by putrefactive bacteria, which break down organic material under oxygen deficient conditions [11]. This process is called "anaerobic digestion”. The digestion process consists of three main phases:

- Hydrolysis,

- Acid formation,

- Methane formation.

In the first phase, protein, carbohydrate and fat are converted to soluble substances followed by acid formation give rise to fatty acids, amino acids and alcohols by acidogenic bacteria. Methane, carbon dioxide, hydrogen sulphide and ammonia form in the third phase by methanogenic bacteria. The slurry becomes somewhat thinner during the process of digestion [12]. The more the two phases merge the shorter the digestion times. The conditions for this are particularly favorable in the "fermentation channel" arrangement. The following types of digestion are distinguished according to the temperature in the digester:

- Psychrophilic digestion $\left(10^{\circ} \mathrm{C}-20^{\circ} \mathrm{C}\right.$, retention time over 100 days $)$,

- Mesophilic digestion $\left(20^{\circ} \mathrm{C}-35^{\circ} \mathrm{C}\right.$, retention time over 20 days),

- Thermophilic digestion $\left(50^{\circ} \mathrm{C}-60^{\circ} \mathrm{C}\right.$, retention time over 8 days).

Thermophilic digestion is not an option for simple plants. The $\mathrm{pH}$ of the fermentation slurry indicates whether the digestion process is proceeding without disturbance. The $\mathrm{pH}$ should be about 7 [4]. This means that the slurry should be neither alkaline nor acid. Biogas can in principle be obtained from any organic material. Cattle manure can be used as a "starter". Feed material containing lignin, such as straw, should be pre-composted and preferably chopped before digestion [5]. More than ten days' preliminary rotting is best for water hyacinth. Gas production is substantially improved if the preliminary rotting time is twenty days.

\subsection{Fermentation Slurry}

All feed materials consist of organic solids, inorganic solids and water. Biogas is formed by digestion of the organic substances. The inorganic materials (minerals and metals) are unused and are unaffected by the digestion process. Adding water or urine gives the substrate fluid properties. This is important for the operation of a biogas plant [5]. It is easier for the methane bacteria to come into contact with feed material which is still fresh when the slurry is liquid. This accelerates the digestion process. Regular stirring thus speeds up the gas production. 
Slurry with a solids content of $5 \%-10 \%$ is particularly well suited to the operation of continuous biogas plants [4] [5].

\subsection{Fermentation Slurry as Fertilizer}

During the digestion process, gaseous nitrogen $(\mathrm{N})$ is converted to ammonia $\left(\mathrm{NH}_{3}\right)$. In this water-soluble form the nitrogen is available to the plants as a nutrient [5]. A particularly nutrient-rich fertilizer is obtained if dung and urine is digested. Compared with solid sludge from fermented straw and grass, the liquid slurry is rich in nitrogen and potassium. The solid fermentation sludge, on the other hand, is relatively richer in phosphorus. A mixture of solid and liquid fermented material gives the best yields. The nutrient ratio is then approximately $\mathrm{N}: \mathrm{P}_{2} \mathrm{O}_{5}: \mathrm{K}_{2} \mathrm{O}=1: 0.5: 1$ [6]. A fermented slurry with a lower $\mathrm{C} / \mathrm{N}$ ratio has better fertilizing characteristics. Compared with fresh manure, increases in yield of $5 \%-15 \%$ are possible [6].

\subsection{Biogas}

Biogas is lighter than air and has an ignition temperature of approximately $700^{\circ} \mathrm{C}$ (diesel oil $350^{\circ} \mathrm{C}$; petrol and propane about $\left.500^{\circ} \mathrm{C}\right)$. The temperature of the flame is $870^{\circ} \mathrm{C}$. Biogas consists of about $60 \%$ methane $\left(\mathrm{CH}_{4}\right)$ and $40 \%$ carbon dioxide $\left(\mathrm{CO}_{2}\right)$ [7]. It also contains small proportions of other substances, including up to $1 \%$ hydrogen sulphide $\left(\mathrm{H}_{2} \mathrm{~S}\right)$. The methane content and hence the calorific value is higher the longer the digestion process. The methane content falls to as little as $50 \%$ if retention time is short [10]. If the methane content is considerably below $50 \%$, biogas is no longer combustible [10] [11]. The first gas from a newly filled biogas plant contains too little methane. The gas formed in the first three to five days must therefore be discharged unused. The methane content depends on the digestion temperature. Low digestion temperatures give high methane content, but less gas is then produced [11].

\section{Methods and Data Sources}

\section{Experimental Set up and Design}

A biogas plant consisting of a $6 \mathrm{~m}^{3}$ tubular enclosed in Ultra Violet (UV) screen house and cleaning accessories was installed at Jomo Kenyatta University of Agriculture and Technology, Kenya. Water hyacinth/cow dung blend $(1500 \mathrm{~kg}$ ) was fed into the digester and allowed to generate gas. Temperature, $\mathrm{pH}$, gas yield and gas compositions were determined for a period of twelve months. The digester was installed with three sample collection points. Samples were collected to monitor changes. All parameters were analyzed using standard procedures [12]. A similar experiment was conducted with cow dung as feed to serve as control for the experiment. The biogas production process is illustrated in Figure 1.

\section{Results and Discussion}

\subsection{Temperature Variations}

Temperature variations are illustrated in Figure 2. It varied widely during the biogas production period. The temperature varied between $22.8^{\circ} \mathrm{C}-36.6^{\circ} \mathrm{C}$, the fermentation process is an exothermic process and the variations could be attributed to the microbial action at various stages of decomposition.

\section{2. $\mathrm{pH}$ Variations}

$\mathrm{pH}$ variations are illustrated in Figure 3. $\mathrm{pH}$ varied widely during the digestion process. The variations can be attributed to the bacterial action during the hydrolysis, acidification and methanization of feed. The processes produce hydroxyl and hydrogen ions thus varying the pH. It ranged between 7.4 - 8.5.

\subsection{Biogas Production}

Biogas production profile with time is presented in Figure 4. The gas production has a maxima on the $32^{\text {nd }}$ day. This can be related to the growth of bacteria within the digester after the $32^{\text {nd }}$ day the bacteria start to starve and competition for food and elimination. The reduced population of the microbes leads to a significant drop in gas production. This can be improved by periodic loading the digester with fresh feedstock. 


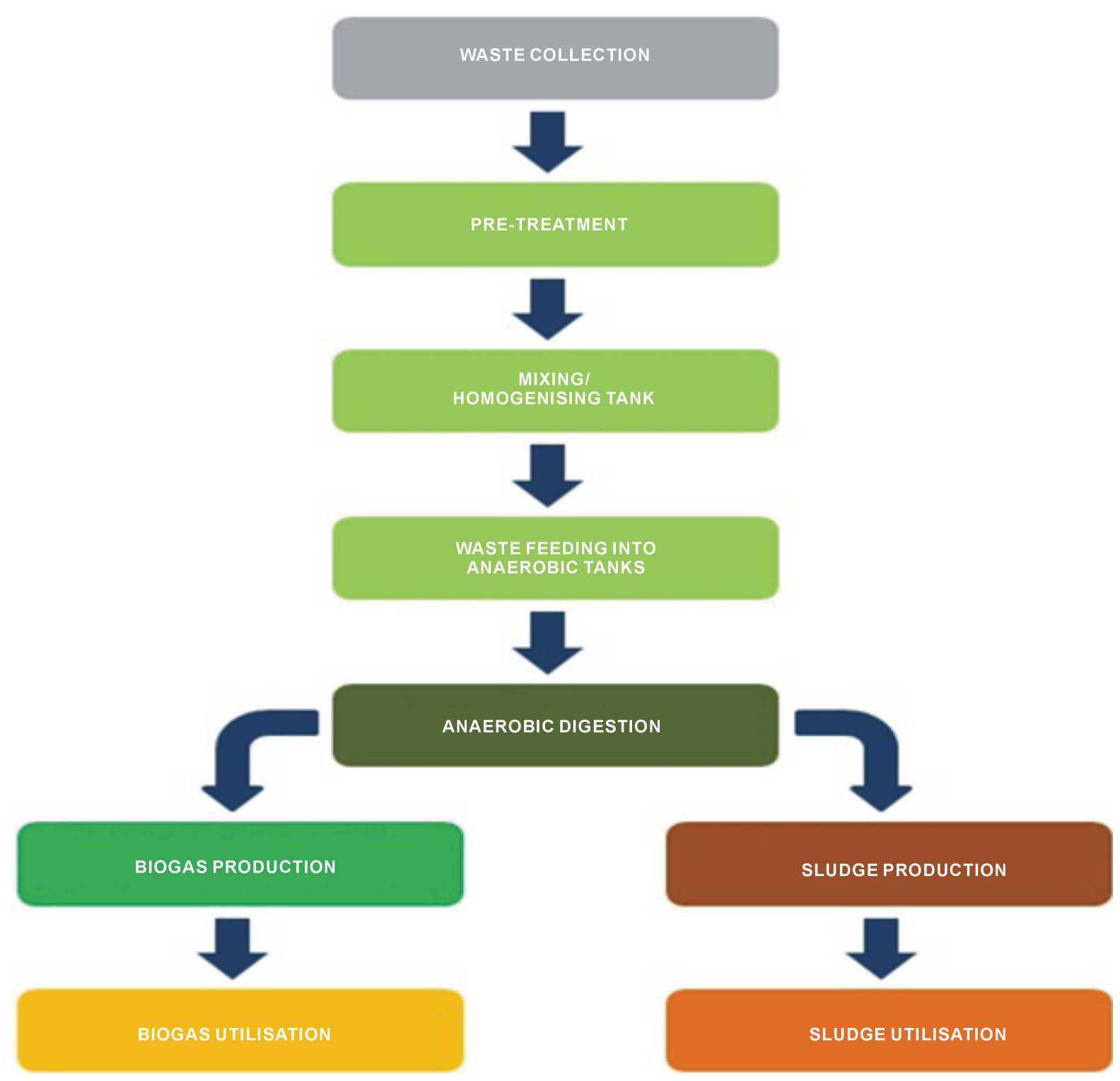

Figure 1. Biogas production process.

\subsection{Biogas Composition}

Table 1 and Figure 5 present data on the retention times of the various constituents of biogas. The gas was found to contain a mix of gases. On average the biogas was found to contain between $49 \%-53 \%$ methane $\left(\mathrm{CH}_{4}\right)$, $30 \%$ - 33\% carbon dioxide $\left(\mathrm{CO}_{2}\right), 5 \%-6 \%$ nitrogen $\left(\mathrm{N}_{2}\right)$ and traces of hydrogen sulphide $\left(\mathrm{H}_{2} \mathrm{~S}\right)$.

\subsection{Biogas Upgrading}

The gas was upgraded by a series of cleaning devices, water vapour was removed using analytical grade sodium sulphate $\left(\mathrm{NA}_{2} \mathrm{SO}_{4}\right), \mathrm{H}_{2} \mathrm{~S}$ removed using iron oxide and $\mathrm{CO}_{2}$ using $15 \%$ sodium Hydroxide solution $(\mathrm{NaOH})$. Table 2 and Figure 6 present data for upgraded gas. There was increase in the methane content by between $21 \%$ $23 \%$.

\subsection{Comparative Biogas Production $\left(\mathrm{m}^{3}\right)$ with Time (Days)}

A comparative biogas production study was conducted for water hyacith/cowdung mixture and cowdung only. 


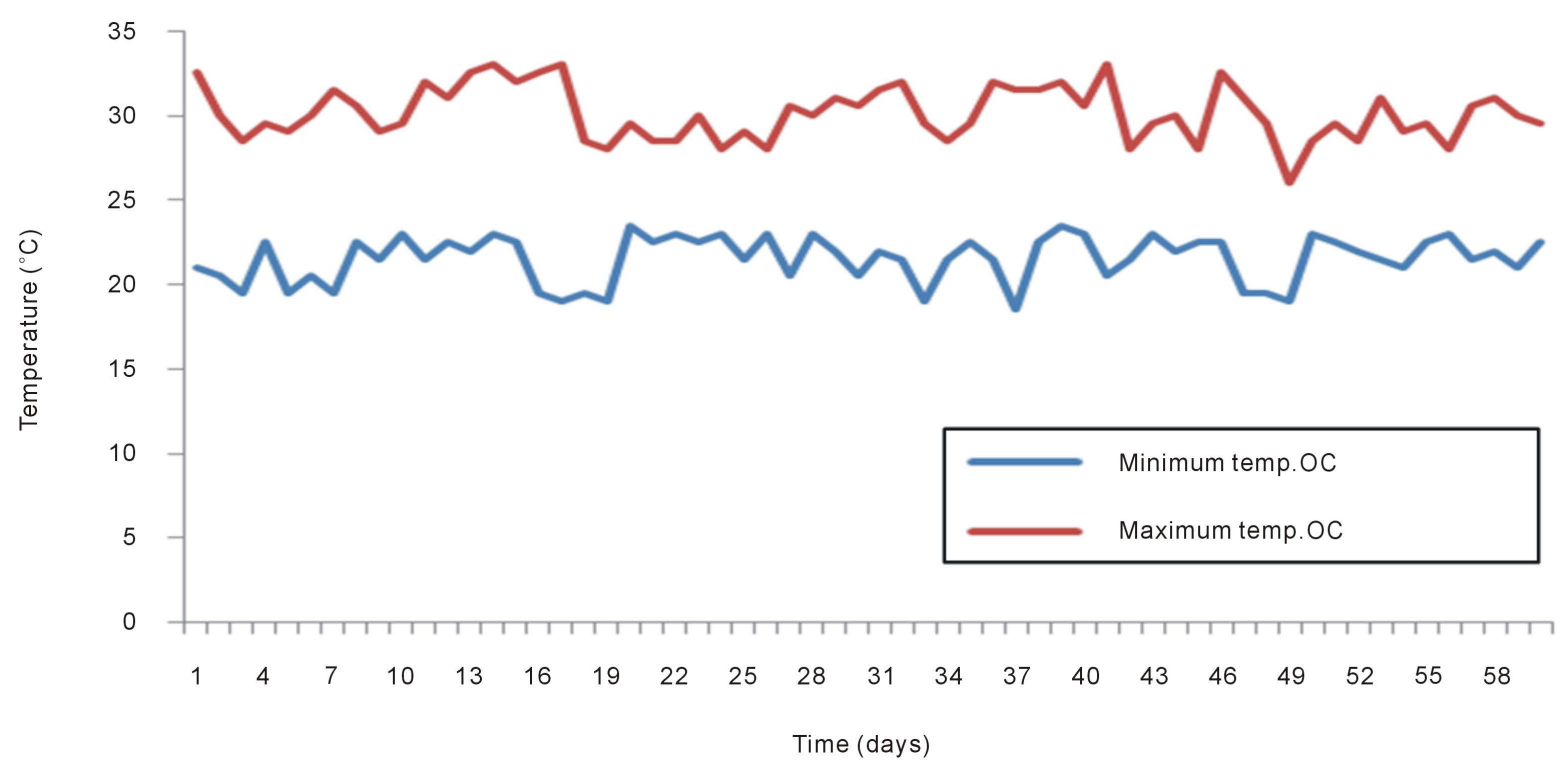

Figure 2. Temperature variation within the biogas digester.



Figure 3. pH variations within the biogas digester.

The results are presented in Figure 7. The cowdung feedstock was found to produce biogas from the fourth day rising to a high on the eigth day which remained almost constant reaching a maxima between the 28 - $36^{\text {th }}$ day.

The biogas production from the water hyacith/cowdung mixture showed a different trend; biogas production remained low than that from cowdung between the fourth and the $18^{\text {th }}$ day but rose steadly to reach a maxima at the $32^{\text {nd }}$ day and remained constant up to the $36^{\text {th }}$ day. The trends show a rather similar trend bu the delay during the first few days for water hyacinth/cow dung mixture can be attributed to the low bacteria population in the matrix. The study shows a greter yield of biogas from the hyacinth/cow dung mixture compared to cow dung. The results of the study agree with those reported by other researchers using water hyacinth as a feed stock [13]-[16].

\section{Conclusion}

The study shows that $E$. crassipes is a good feedstock and that can be utilized as a renewable energy source. The 




Figure 4. Biogas production with time.

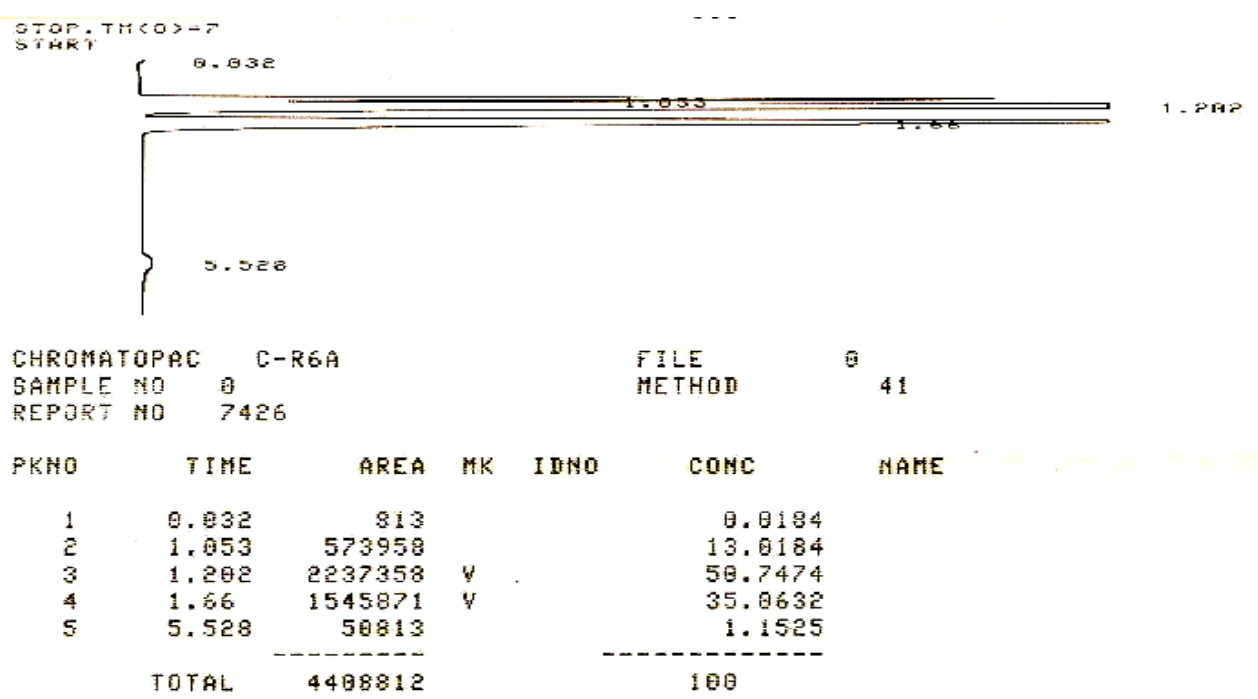

Figure 5. Chromatogram for raw biogas.

Table 1. Raw biogas composition.

\begin{tabular}{ccc}
\hline Composition & Retention time (min) & Percentage composition \\
\hline Nitrogen & 1.02 & $17.0 \%-19.0 \%$ \\
Methane & 1.12 & $49.0 \%-53.0 \%$ \\
Carbon dioxide & 1.62 & $21.0 \%-29.0 \%$ \\
\hline
\end{tabular}

Table 2. Biogas composition after upgrading.

\begin{tabular}{ccc}
\hline Composition & Retention time (min) & Percentage composition (\%) \\
\hline Nitrogen & 1.02 & $19.0 \%-27.0 \%$ \\
Methane & 1.12 & $65.0 \%-73.0 \%$ \\
Carbon dioxide & 1.62 & $4.0 \%-8.0 \%$ \\
\hline
\end{tabular}




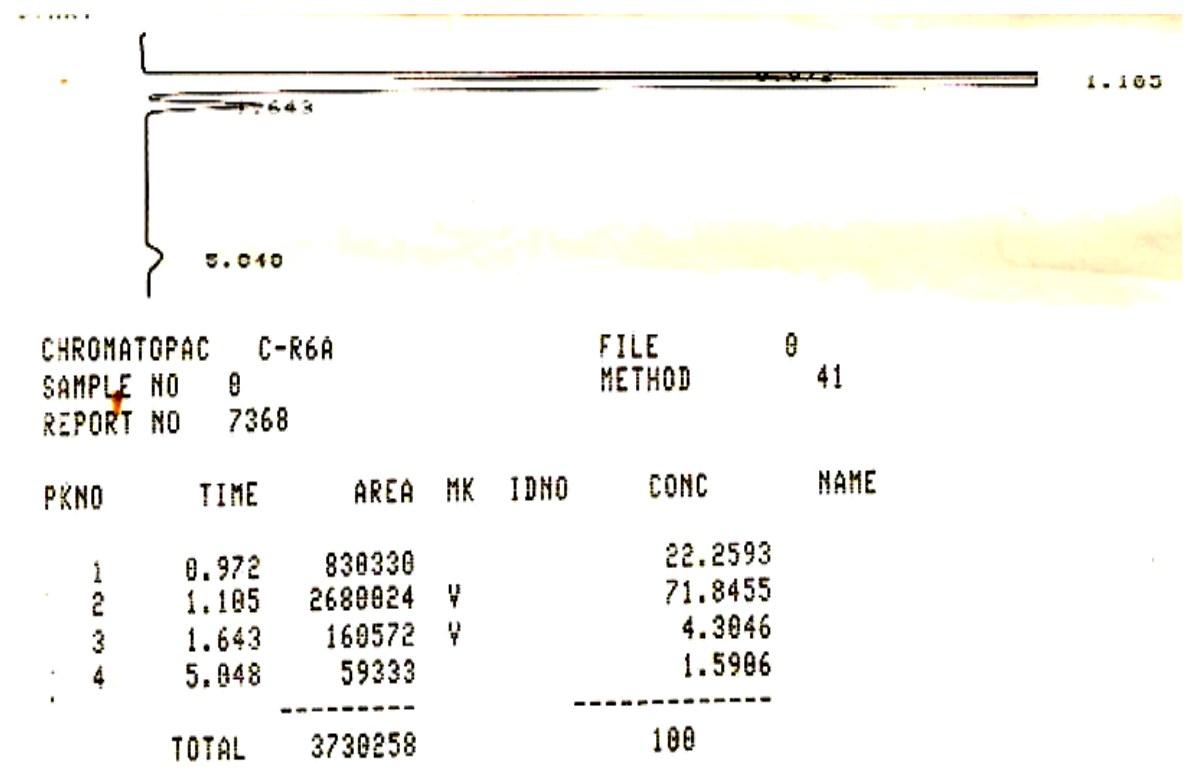

Figure 6. Chromatogram for upgraded biogas.

Cumulative biogas volume

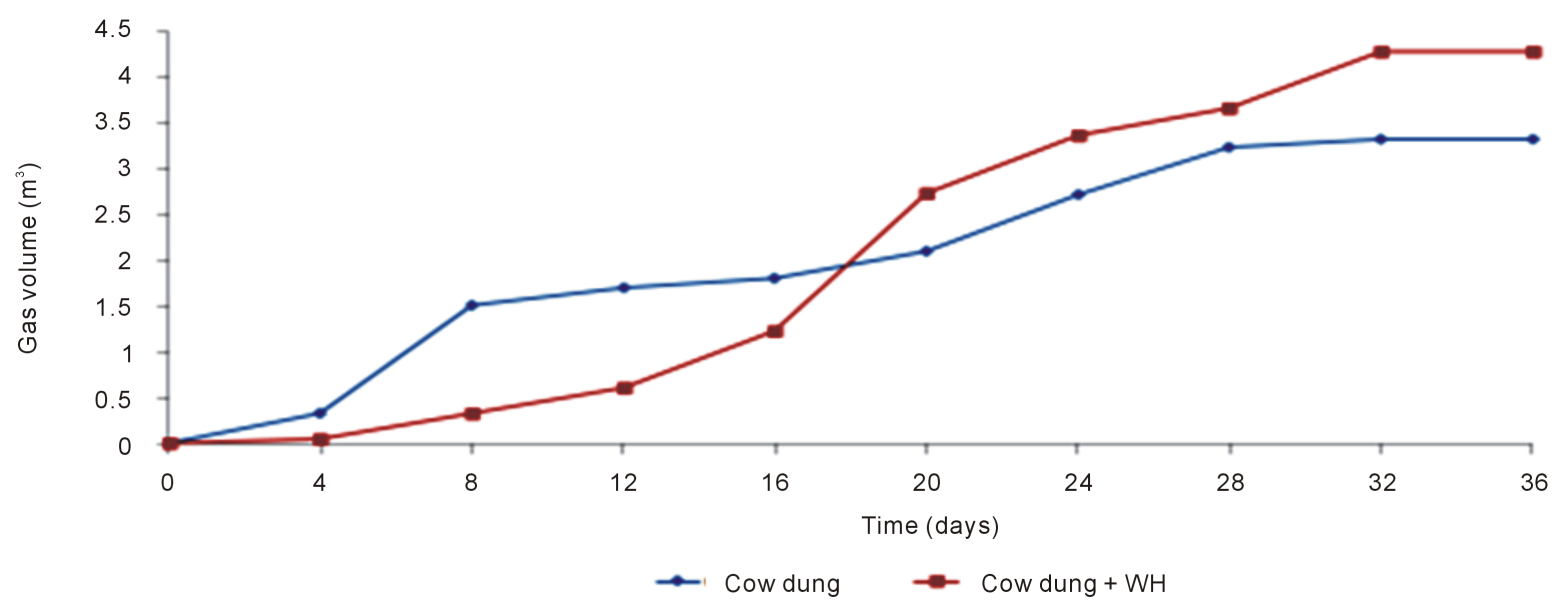

- Biogas production in both Cow dung and Cow dung and WH mixture rose significantly.

- The total volume of biogas produced during the period for cow dung was $3.34 \mathrm{~m}^{3}$ and Cow dung and Water hyacinth $4.83 \mathrm{~m}^{3}$.

Figure 7. Biogas production with time (days).

production profiles compares well with those of conventional feed stocks such as cow dung. The utilization also provide an innovative way of managing the invasion of the weed in freshwater bodies in an environmentally sound manner.

\section{Acknowledgements}

The authors gratefully acknowledge to the Japan International Cooperation Agency (JICA) and BRIGHT project of JICA for the financial support throughout this study.

\section{References}

[1] Burke, D. (2001) Dairy Waste Anaerobic Digestion Handbook. Options for Gy Company, Olympia, WA. 
[2] Dohanyos, M. and Zabranska, J. (2001) Anaerobic Digestion, Chap.13. In: Spinosa, L. and Vesilind, P.A., Eds., Sludge Into Biosolids, IWA Publishing.

[3] FAO/CMS (1996) A System Approach to Biogas Technology. Biogas Technology: A Training Manual for Extension. http://www.fao.org

[4] International Energy Agency (IEA) (2005) Biogas Production and Utilization. IEA Bio-Energy. www.iea-biogas.net

[5] Ludwig, S. (1988) Biogas Plants, A Publication of the Deutsches Zentrum für Entwicklungstechnologien - gATE. In: Deutsche Gesellschaft für Technische Zusammenarbeit (GTZ).

[6] McCann, J.A., et al. (1996) Nonindigenous Aquatic and Selected Terrestrial Species of Florida-Status, Pathway, and Time of Introduction, Present Distribution, and Significant Ecological and Economic Effects. Southeastern Biological Science Center, Gainesville, 256 pp.

[7] Schmitz, D.C., Schardt, J.D., Leslie, A.G., Dray, F.A., Osborne, J.A. and Nelson, B.V. (1993) The Ecological Impact and Management History of Three Invasive Alien Aquatic Plants in Florida. In: McKnight, B.N., Ed., Biological Pollution-The Control and Impact of Invasive Exotic Species, Indiana Academy for Science Math \& Humanities, Indianapolis, 261.

[8] Langeland, K.A. and Cherry, H.M. (2008) Identification and Biology of Nonnative Plants in Florida's Natural Areas. 2nd Edition, University of Florida-IFAS Publication \# SP 257.

[9] Simpson, D. and Sanderson, H. (2002) Eichhornia crassipes. Curtis’s Botanical Magazine, 19, 28-34. http://dx.doi.org/10.1111/1467-8748.00326

[10] Van, T.K. and Steward, K.K. (1982) Evaluation of Chemicals for Aquatic Plant Control. Annual Report 1981, Ft. Lauderdale, FL, 66 pp.

[11] Vandiver, V.V. (1999) Florida Aquatic Weed Management Guide. Univ. of FL, IFAS, Cooperative Extension Service, Publ. SP-55, $130 \mathrm{pp}$

[12] APHA (1995) Standard Methods for Analysis, America Public Health Association, 1995.

[13] Zupančič, G.D. and Grilc, V. (2009) Anaerobic Treatment and Biogas Production from Organic Waste Institute for Environmental Protection and Sensors Slovenia. www.intechopen.com

[14] Almoustapha, O., Kenfack, S. and Millogo-Rasolodim, J. (2009) Biogas Production Using Water Hyacinths to Meet Collective Energy Needs in a Sahelian Country. Field Actions Science Reports, 2, 27-32. www.field-actions-sci-rep.net/2/27/2009/

[15] Sudhakar, K. Ananthakrishnan, R. and Goyal, A. (2013) Biogas Production from a Mixture of Water Hyacinth, Water Chestnut and Cow Dung. International Journal of Science, Engineering and Technology Research, 2, 35-37.

[16] Kunatsa, T. and Mufundirwa, A. (2013) Biogas Production from Water Hyacinth Case of Lake Chivero - Zimbabwe A Review. International Journal of Recent Technology and Engineering, 2, 135-142. 